\title{
Nowa strategia leczenia częściowej głuchoty - 18 lat doświadczeń własnych
}

\section{New strategy of partial deafness treatment - 18 years of experience}

\author{
Henryk Skarżyński ${ }^{1}$, Piotr H. Skarżyński ${ }^{1,2,3}$ \\ ${ }^{1}$ Instytut Fizjologii i Patologii Słuchu, Światowe Centrum Słuchu, Warszawa/Kajetany \\ ${ }^{2}$ Warszawski Uniwersytet Medyczny, Zakład Niewydolności Serca i Rehabilitacji Kardiologicznej, Warszawa \\ ${ }^{3}$ Instytut Narządów Zmysłów, Kajetany
}

Adres autora: Henryk Skarżyński, Światowe Centrum Słuchu, ul. Mokra 17, Kajetany, 05-830 Nadarzyn, e-mail: skarzynski.henryk@ifps.org.pl

\section{Streszczenie}

Leczenie klasycznej częściowej głuchoty stanowiło wielkie wyzwanie kliniczne. Trudność polegała na takim wszczepieniu implantu ślimakowego, aby zachować istniejące u pacjenta resztki słuchowe, a następnie połączyć słuch akustyczny ze stymulacją elektryczną zapewnianą przez implant. W szczególności dotyczyło to pacjentów, u których słuch w zakresie niskich częstotliwości był w normie i niezbędne było tylko jego elektryczne dopełnienie w zakresie średnich i wysokich częstotliwości. Przeprowadzona w 2002 roku przez H. Skarżyńskiego pierwsza w świecie operacja wszczepienia implantu osobie dorosłej z częściową głuchotą, a w 2004 r. - dziecku z takim samym uszkodzeniem słuchu wytyczyła nowy kierunek badań naukowych oraz leczenia różnych częściowych, coraz częściej spotykanych uszkodzeń słuchu. Zebranie bardzo dużego materiału, obejmującego 1965 zoperowanych uszu, oraz długi okres obserwacji pozwoliły na przedstawienie nowej koncepcji leczenia częściowej głuchoty, której istotnym elementem jest zachowanie przedoperacyjnego słuchu oraz struktur ucha wewnętrznego. Pierwsze w świecie operacje wszczepienia implantu u pacjentów z częściową głuchotą były poprzedzone kilkuletnimi badaniami nad zachowaniem istniejących niewielkich resztek słuchowych u dorosłych i dzieci. Podjęto próby wykorzystania resztek słuchowych poprzez ich stymulację konwencjonalnymi aparatami słuchowymi i dodatkowo pobudzenie elektryczne za pośrednictwem implantów.

Wyniki tych prac, przedstawione w 2000 r. podczas konferencji ESPCI w Antwerpii i Kongresu EUFOS w Berlinie, wskazywały na potrzebę rozszerzenia pierwszych ostrożnych wskazań do stosowania implantów ślimakowych w przypadku zachowanych w różnym stopniu resztek słuchowych w zakresie niskich częstotliwości. Podczas 18 lat upowszechniania w świecie metody leczenia częściowej głuchoty udokumentowano dużą grupę zoperowanych uszu z częściową głuchotą oraz wykazano zasadność przyjętych wskazań i założeń chirurgicznych. W szczególności dotyczą one opracowania przez H. Skarżyńskiego strategii operacyjnej opartej na wykonaniu 6 zasadniczych kroków dojścia do schodów bębenka przez okienko okrągłe i wykorzystaniu niezwykle delikatnych elektrod o długości części aktywnej od 20 do $28 \mathrm{~mm}$. Podsumowaniem metody leczenia częściowej głuchoty było opublikowanie w 2010 r. nowego kompleksowego podejścia do zachowania istniejącego w różnym stopniu przedoperacyjnego słuchu oraz zachowania struktury ślimaka. Pozwoliło to na zaproponowanie przez Skarżyńskiego i zaproszonych do współpracy ekspertów z całego świata nowej klasyfikacji przeznaczonej do oceny wyników leczenia częściowej głuchoty oraz prezentacji efektów terapii homogennych grup pacjentów. Poza opracowaniem metod chirurgicznych autor koncepcji leczenia częściowej głuchoty przyczynił się do stworzenia nowych, różnej długości niezwykle delikatnych elektrod implantów ślimakowych. Całość podjętych działań zaowocowała rozszerzeniem wskazań do leczenia za pomocą implantów ślimakowych różnych postaci częściowej głuchoty.

Słowa kluczowe: leczenie częściowej głuchoty • zachowanie słuchu • stymulacja elektryczna i akustyczna • implanty ślimakowe • klasyfikacja częściowej głuchoty • okienko okrągłe

\begin{abstract}
Possibility of preserving different preoperative residual hearing, and in particular treatment of the classic partial deafness, posed a great clinical challenge to preserve the preoperative hearing and supplement it with the electric stimulation through the implant. It especially concerned cases when hearing in the low frequency range was normal or fully efficient and it was necessary only to supplement it electrically in the middle and high frequency range. Surgeries performed since 1997, which consisted in preservation of the preoperative residual hearing, showed a new direction of studies in world medicine. First in the
\end{abstract}


world surgery of electric complementation, performed in 2002, to the existing normal hearing, performed by H. Skarżyński 13 years ago, have set a new direction in the treatment of different, more and more frequent partial hearing losses. Long follow up period and accumulation of very large material of 1965 operated ears enabled presenting the new idea of partial deafness treatment, preservation of preoperative hearing and unchanged inner ear structure. The first surgery of electric complementation of the existing hearing in an adult has been performed in 2002, and in 2004 it has been performed for the first time in child with this type of hearing. They had been preceded by several years of studies on preservation of the existing small residual hearing in children and adults. Attempts were made to use the residual hearing through its stimulation with a typical hearing aid and additional electric stimulation with an implant. This residual hearing had been amplified with the conventional hearing aids and stimulated electrically with implants. Results of these studies, presented in 2000 during the ESPCI conference in Antwerp and the EUFOS Congress in Berlin, demonstrated the need to extend the initial conservative indications for cochlear implantation in cases of the preserved to a different degree low frequency residual hearing. Documentation of the large group of operated ears with partial deafness during 18 years of spreading this method in the world demonstrated the soundness of the adopted indications and surgical guidelines. This concerns in particular the development by of the surgical strategy H. Skarżyński based on 6 principal surgical steps to approach the scala tympani through the round window and use the extremely delicate electrodes with active length of 20 to $28 \mathrm{~mm}$. The summary of the whole strategy was the publication in 2010 of the new comprehensive approach to preservation of preoperative hearing present in different degrees and to preservation of the cochlea structure. It allowed H. Skarżyński and invited experts from the whole world to introduce a new classification for assessment of the results of treatment of the partial deafness and for evaluation of the results of therapy in the homogenous group of patients. Additionally to the surgical activities the author of the conception influenced development of new different - length extremely delicate cochlear implant electrodes. All of these activities led to the extension of indications for treatment of various forms of the partial deafness with cochlear implants.

Key words: partial deafness treatment $\bullet$ preservation of hearing $\bullet$ electric-acoustic stimulation $\bullet$ cochlear implants $\bullet$ classification of deafness $\bullet$ round window approach (surgical techniques)

\section{Wstęp}

Uzyskiwane coraz lepsze rezultaty leczenia głębokiego niedosłuchu i głuchoty, zwłaszcza u coraz młodszych dzieci, zachęcały naukowców do stałego rozszerzania wskazań do metody leczenia za pomocą implantów ślimakowych. Poszukiwania te były prowadzone niezależnie w Europie [1], w USA [2] i w Australii [3]. Dotyczyły one zwykle stymulacji elektrycznej za pośrednictwem implantu na jedno ucho i jednoczesnej stymulacji akustycznej aparatem słuchowym po stronie przeciwnej, rzadziej jednostronnej stymulacji akustycznej i elektrycznej w tym samym uchu. W 2002 r. podczas V Konferencji ESPCI w Antwerpii H. Skarżyński przedstawił [4] pierwsze wyniki badań audiometrycznych w grupie dzieci z resztkami słuchowymi, korzystających $z$ implantu ślimakowego przez 3 lata, które wskazywały na możliwość zachowania słuchu po wszczepieniu implantu. W tym samym roku podczas Kongresu EUFOS zostały zaprezentowane wyniki zachowania resztek słuchowych u pierwszej grupy pacjentów dorosłych [5]. Kilkuletnia obserwacja zachowania niewielkich resztek słuchowych wykazała, że zasadne jest rozszerzenie wskazań do stosowania implantów ślimakowych jako elektrycznego dopełnienia słuchu dla częstotliwości powyżej $500 \mathrm{~Hz}$ [6]. Elektryczne dopełnienie zastosował po raz pierwszy w świecie H. Skarżyński - w 2002 r. u pacjenta dorosłego [7], a w 2004 r. u dziecka [8]. Procedura operacyjna służąca zachowaniu resztek słuchowych, która została zaproponowana przez Skarżyńskiego, to strategia 6 kroków, uwzględniających dojście do schodów bębenka przez okienko okrągłe jako najmniej inwazyjnej drogi wprowadzenia elektrody do ucha wewnętrznego [6]. Stała obserwacja coraz większej grupy pacjentów - początkowo liczącej kilkuset, a następnie ponad tysiąc osób - oraz osiąganie dobrych wyników długoterminowych wskazuje na pełną zasadność rozwijania tego kierunku. Potwierdzeniem były kolejne liczne doniesienia i stała prezentacja materiału na wszystkich kontynentalnych konferencjach i światowych kongresach poświęconych implantom słuchowym, audiologii i otologii, które odbyły się w ostatnich latach $[9,10]$. Celem była systematyczna prezentacja nowych grup pacjentów, dłuższego czasu obserwacji, wyników zachowania słuchu oraz pokazanie nowych technologii elektrod w implantach ślimakowych [11-13]. Pozwoliło to na przedstawienie w 2009 r., podczas IX Konferencji ESPCI w Warszawie, nowej koncepcji leczenia częściowej głuchoty, uwzględniającej pacjentów $\mathrm{z}$ różnym przedoperacyjnym słuchem w zakresie niskich częstotliwości [14]. W roku 2010 została opublikowana [6] nowa, kompleksowa koncepcja pozwalająca pokazać różnice w podejściu do różnych grup pacjentów z częściową głuchotą (rycina 1).

Wszystkie zabiegi operacyjne w omawianej metodzie leczenia częściowej głuchoty zostały przeprowadzone wg procedury 6 kroków pozwalającej na zachowanie istniejącej struktury ucha wewnętrznego $[6,14,15]$. Wraz z rozwojem metody chirurgicznej oraz stałym rozszerzaniem wskazań do stosowania implantów ślimakowych u coraz większej grupy pacjentów kolejne kroki milowe odnosiły się do wpływu tych działań na rozwój nowych technologii. Jednym z głównych kierunków rozwoju był rozwój elektrod o różnej długości części czynnej elektrody w implantach ślimakowych [15]. Jednym z ostatnich elementów rozwoju tej strategii było zastosowanie stymulacji elektrycznej za pomocą elektrod o długości części aktywnej od 20 do $25 \mathrm{~mm}[12,13]$. Najnowszym podejściem jest zastosowanie głębszego wprowadzenia elektrody - do $28 \mathrm{~mm}$ - przy zachowaniu istniejącego słuchu na częstotliwości $250 \mathrm{~Hz}$ i powyżej, co stworzyło realną szansę na bardziej efektywną stymulację elektryczną szczytowej części ślimaka [16]. Ostatnim ważnym krokiem w rozwoju najnowszej koncepcji leczenia częściowej głuchoty było opracowanie wspomnianej pierwszej klasyfikacji częściowej głuchoty wg Skarżyńskiego i wsp. [6]. Ma to bardzo istotne znaczenie w dalszym opracowywaniu wyników homogennych grup pacjentów z różnym poziomem istniejącego zachowanego 

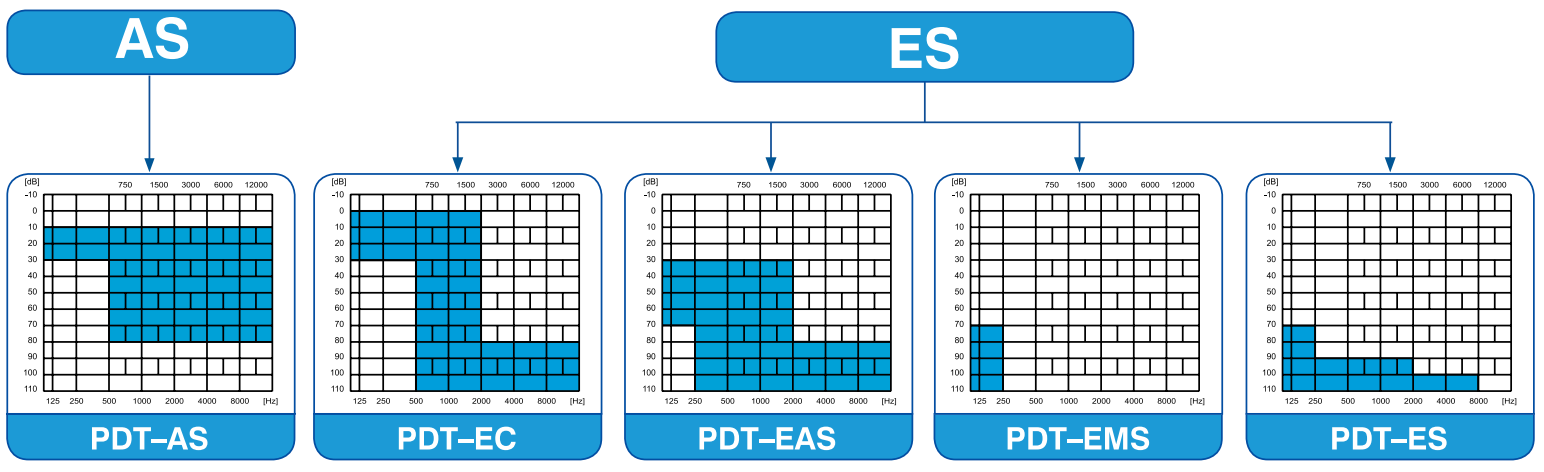

Rycina 1. Nowa koncepcja wykazania zakresów akustycznej (AS) i elektrycznej (ES) stymulacji w leczeniu częściowej głuchoty wg Skarżyńskiego: (A) jako wzmocnienia akustycznego słuchu za pośrednictwem aparatów słuchowych i implantów ucha środkowego (PDT-AS), (B) jako elektrycznego dopełnienia istniejącego dobrego słuchu na niskich częstotliwościach (PDT-EC), (C) jako akustycznego wzmocnienia zachowanych resztek słuchowych w zakresie niskich częstotliwości za pośrednictwem aparatu słuchowego i elektrycznej stymulacji pozostałej części tego samego ucha (PDT-EAS). Łączona stymulacja elektroakustyczna jest możliwa w systemach Duet lub Hybrid, (D) jako zmodyfikowaną stymulację elektryczną w przypadkach utraty przedoperacyjnego słuchu bez konieczności wykonywania reoperacji (PDT-EMS), (E) jako wyłącznie stosowaną stymulację elektryczną w istniejących niefunkcjonalnych resztkach słuchowych na różnych częstotliwościach (PDT-ES)

Figure 1. New conception of demonstrating the extent of acoustic (AS) and electric (ES) stimulation in the treatment of partial deafness according to H. Skarżyński: (A) as acoustic amplification of hearing with hearing aids and middle ear implants (PDT-AS), (B) as electric complementation of the existing good hearing in low frequencies (PDT-EC), (C) as acoustic amplification of the preserved residual hearing in low frequency range using hearing aids, with the electric stimulation of the other part of the same ear (PDT-EAS). Combined electroacoustic stimulation is possible in Duet and Hybrid systems, (D) as modified electric stimulation in cases of loss of preoperative hearing without the need for revision surgery (PDT-EMS), (E) as the only applied electric stimulation in cases of present nonfunctional residual hearing in different frequencies (PDT-ES)

przedoperacyjnego słuchu po wszczepieniu implantu ślimakowego. Możliwość porównania wyników osiąganych przez różnych autorów, z zastosowaniem różnych typów implantów, w zróżnicowanych pod względem czułości słuchu grupach pacjentów ułatwi dalsze rozszerzenie wskazań i upowszechnianie metody leczenia częściowej głuchoty. Jednocześnie miało to znaczący wpływ na rozwój nowych technologii w zakresie organizacji opieki pooperacyjnej, np. tworzenie sieci telemedycznych, i wykorzystania wielu technologii w obszarze e-zdrowia. Niezwykle dobry odbiór rezultatów leczenia częściowej głuchoty przez środowisko pacjentów i ich rodzin miał wpływ na organizację nowego zaplecza, czego przykładem jest Światowe Centrum Słuchu $[17,18]$.

\section{Materiał i metody}

\section{Materiał}

W ciągu 18 lat metodę leczenia PDT zastosowano w 1965 uszach u dzieci i dorosłych w wieku od 9 miesięcy do 84 lat. W tej grupie dzieci i młodzież do 18 r.ż. stanowią 26,7\%, a osoby dorosłe $73,3 \%$. Dla określenia przedoperacyjnych progów słyszenia, u dzieci powyżej 5 roku życia i u dorosłych, zastosowano badania audiometrii tonalnej. U dzieci młodszych podstawą do oceny przedoperacyjnego progu słyszenia było badanie ABR na częstotliwości $0,5 \mathrm{kHz}$, $1 \mathrm{kHz}, 2 \mathrm{kHz}$ i $4 \mathrm{kHz}$. Należy podkreślić, że najistotniejszą grupą byli pacjenci, których niedosłuch charakteryzuje się prawidłową bądź w niewielkim stopniu obniżoną czułością w zakresie do $500 \mathrm{~Hz}$ oraz brakiem czułości dla wysokich częstotliwości - PDT-EC (ang. Partial Deafness Treatment - Electric Complement) [6]. Jako grupa wymagająca jedynie dopełnienia elektrycznego istniejącego słuchu stanowili oni największe wyzwanie dla operatora, ale jednocześnie byli grupą predysponowaną do uzyskiwania najlepszych i najszybszych efektów w pooperacyjnej rehabilitacji. Druga grupa - PDT-EAS (ang. Partial Deafness Treatment - Electric Acoustic Stimulation) (rycina 1), w której stosuje się łączoną stymulację elektryczno-akustyczną, była do tej pory najliczniejsza. Wynikało to zapewne z faktu, że pacjenci ci byli najbardziej zdeterminowani, by poddać się operacji wszczepienia implantu. Trzecia grupa - PDT-EMS (ang. Partial Deafness Treatment - Electric Modified Stimulation) (rycina 1) była najmniejsza - liczyła 6 dzieci oraz 42 osoby dorosłe, co stanowi $2,4 \%$ całej zoperowanej populacji 1965 uszu. Wśród 42 pacjentów dorosłych, u których doszło w ciągu 6 miesięcy do istotnej utraty słuchu przedoperacyjnego, u 27 (1,4\% całej zoperowanej populacji) osób zaobserwowano pogorszenie słuchu obustronne, czyli nie tylko w uchu zoperowanym, a u 15 osób dorosłych $(0,7 \%)$ - jednostronne - tylko w uchu operowanym. Należy to wiązać $\mathrm{z}$ faktem wykonania zabiegu operacyjnego. Wśród dzieci istotne pogorszenie słuchu odnotowano jedynie w 6 uszach. Stanowi to $0,3 \%$ całej zoperowanej populacji i $1,1 \%$ populacji dziecięcej. Co jest znamienne, w okresie 3 miesięcy po operacji u tych dzieci doszło do pogorszenia słuchu jedynie w uchu operowanym i nie obserwowano obustronnego pogorszenia słuchu. Uzyskany efekt zachowania słuchu przedoperacyjnego utrzymywał się przez 7 lat u $100 \%$ zoperowanych dzieci.

\section{Metody}

We wszystkich zoperowanych uszach dojście do schodów bębenka następowało przez okienko okrągłe. W 99,6\% 
Tabela 1. Procedura chirurgiczna leczenia częściowej głuchoty za pomocą implantu ślimakowego wg Skarżyńskiego Table 1. Surgical procedure for partial deafness treatment with cochlear implants according to Skarżyński

\begin{tabular}{ll}
\hline \multicolumn{1}{c}{ Krok } & \multicolumn{1}{c}{ Opis } \\
\hline 1 & Zachowawcza antromastoidektomia \\
\hline 2 & Tympanotomia tylna w celu uwidocznienia niszy okienka okrągłego \\
\hline 3 & Przekłucie i nacięcie błony okienka okrągłego \\
\hline 5 & $\begin{array}{l}\text { Wprowadzenie elektrody do schodów bębenka bezpośrednio przez błonę okienka okrągłego (pełne lub częściowe } \\
\text { włożenie elektrody) }\end{array}$ \\
\hline 6 & $\begin{array}{l}\text { Zamocowanie elektrody w niszy okienka okrągłego za pomocą kleju tkankowego (błonę należy zostawić częściowo } \\
\text { odsłoniętą, by zachować jej mobilnośc) }\end{array}$ \\
\hline
\end{tabular}

A

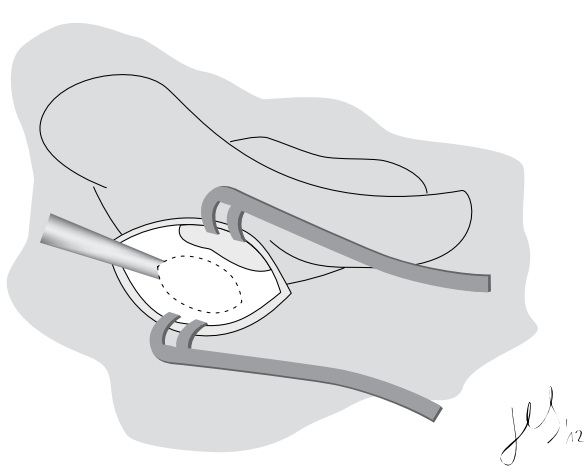

B

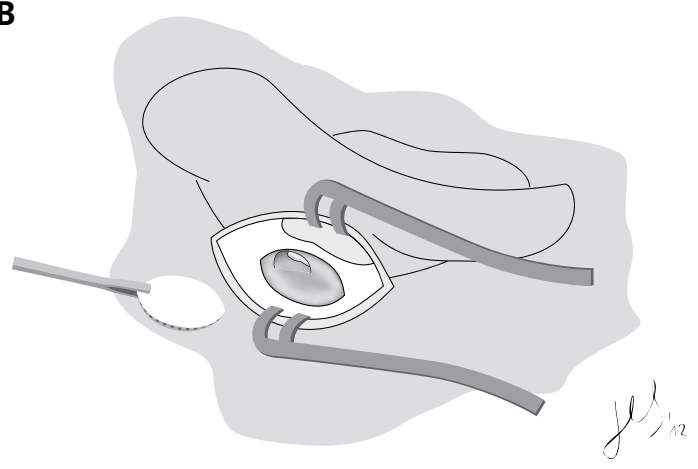

uszach było możliwe dojście do niszy okienka poprzez tympanotomię tylną, a jedynie w 7 przypadkach $(0,4 \%)$ $\mathrm{z}$ dojścia podwójnego przez tympanotomię tylną i przez przewód słuchowy zewnętrzny. W tej ostatniej grupie przez przewód słuchowy zewnętrzny zapewniano wgląd do niszy okienka okrągłego, a elektrodę wprowadzano od tyłu przez wcześniej wykonaną tympanotomię tylną. Zatem w każdym uchu możliwe było delikatne wprowadzenie do schodów bębenka - przez naciętą błonę okienka okrągłego - elektrody o wymaganej długości. Procedura operacyjna była przeprowadzona zgodnie ze standardem zaproponowanym przez Skarżyńskiego [6,14], który obejmuje 6 zasadniczych kroków (tabela 1).

Pierwszym krokiem jest wykonanie konserwatywnej antromastoidektomii, czyli nie szerokiego, ale wystarczającego dla potrzeb przeprowadzenia elektrody otwarcia jamy wyrostka. Czynnością poprzedzającą otwarcie wyrostka,
C

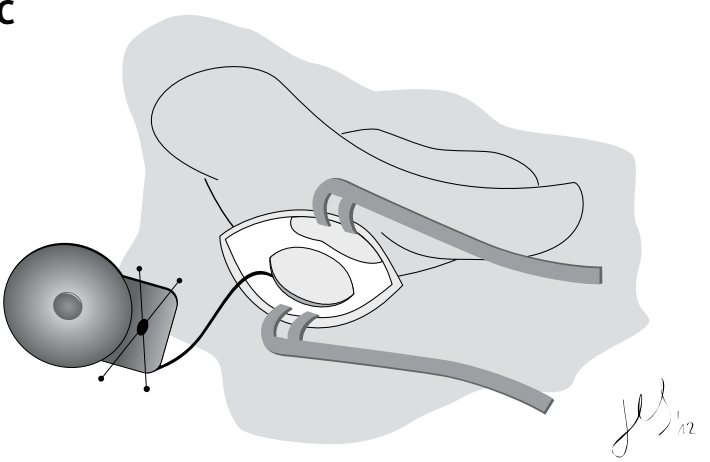

Rycina 2. Schemat wyznaczenia obszaru do pobrania wióra kostnego (A), zdjęcie za pomocą dłuta części warstwy korowej wyrostka (B), zamknięcie pod koniec operacji pobranym wiórem kostnym jamy wyrostka sutkowatego (C) wg Skarżyńskiego

Figure 2. Diagram of determining the area for harvesting the bone chip (A), removal of a part of the cortical layer of the mastoid process with a chisel (B), closure of the mastoid process cavity at the end of surgery with the harvested bone chip (C) according to Skarżyński

szczególnie preferowaną u dzieci, jest zdjęcie za pomocą dłuta fragmentu warstwy korowej w taki sposób, by po wszczepieniu części wewnętrznej implantu fragment ten wykorzystać do całkowitego odizolowania jamy wyrostka od przestrzeni podskórnej, w której mocowana jest część wewnętrzna implantu (rycina 2).

Drugi krok polega na wykonaniu tympanotomii tylnej (rycina 3). Podstawowym założeniem jest takie otwarcie tej drogi, by pod kontrolą wzroku przeprowadzić elektrodę do niszy okienka okrągłego. Dla potrzeb dobrego uwidocznienia błony okienka w niektórych przypadkach znosi się wargę boczną, która w części lub zupełnie zasłania niekiedy wgląd do okolicy błony okienka. W nielicznych przypadkach, jak to podano wyżej, przy niedostatecznym uwidacznianiu się niszy okienka okrągłego sugerowane jest dojście podwójne przez przewód słuchowy zewnętrzny.

Trzeci krok polega na delikatnym nacięciu błony okienka okrągłego w celu przygotowania drogi wejścia elektrody do schodów bębenka (rycina 4). 


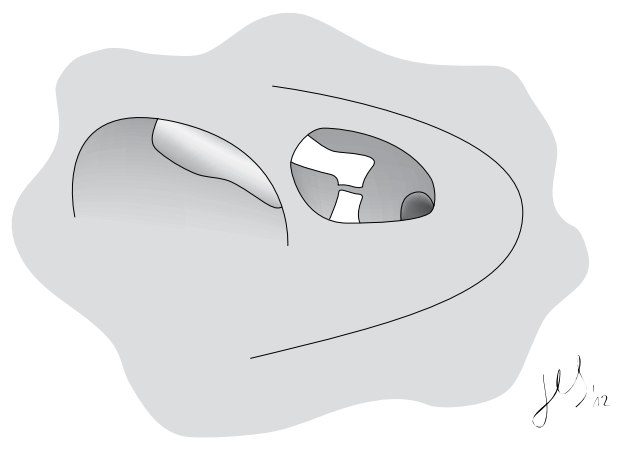

Rycina 3. Tympanotomia tylna umożliwiająca uwidocznienie niszy okienka okrągłego

Figure 3. Posterior tympanotomy to visualize the round window niche

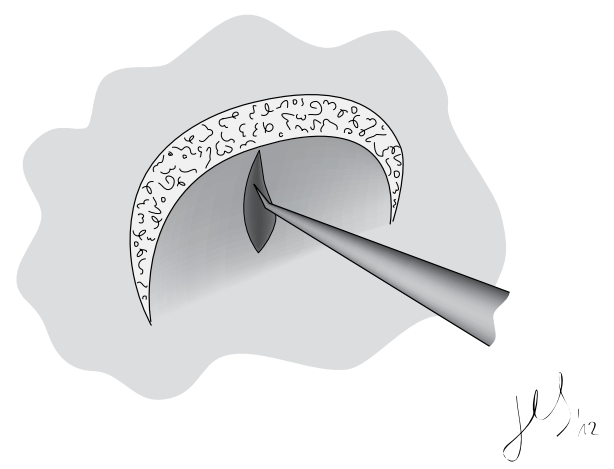

Rycina 4. Trzeci krok procedury chirurgicznej leczenia PDT nacięcie odsłoniętej błony okienka okrągłego

Figure 4. Third step of the surgical procedure for PDT - incision of the exposed round window membrane

Następną, najważniejszą czynnością jest wykonanie kroku czwartego, w ramach którego wprowadza się elektrodę pod kątem zbliżonym do prostego w stosunku do powierzchni błony okienka okrągłego (rycina 5). Takie ustawienie elektrody przed wprowadzeniem do schodów bębenka autor procedury uważa za najmniej traumatyczne. Na początku wprowadzania elektrody do schodów bębenka zalecane jest trzymanie jej w palcach dla lepszego wyczucia oporów. Jedynie końcowe czynności wprowadzania elektrody do schodów bębenka są wykonywane za pomocą kleszczyków.

Piąty krok polega na uszczelnieniu wejścia elektrody do schodów bębenka oraz jej umocowaniu w obrębie tympanotomii tylnej za pomocą fragmentu powięzi i kleju tkankowego (rycina 6). Pozostała część elektrody jest zwijana w jamie wyrostka. Wejście do wyrostka jest zamykane fragmentem spongostanu, na którym za pomocą kleju tkankowego mocowany jest fragment warstwy korowej wyrostka pobrany podczas kroku pierwszego.

Ostatni - 6 krok obejmuje przygotowanie loży dla części wewnętrznej implantu i jej umocowaniu za pomocą cementu jonomerycznego lub niewchłanianych szwów, co uwidoczniono na rycinie $2 \mathrm{C}$. Zakończenie zabiegu operacyjnego polega na założeniu na 2 dni u wszystkich

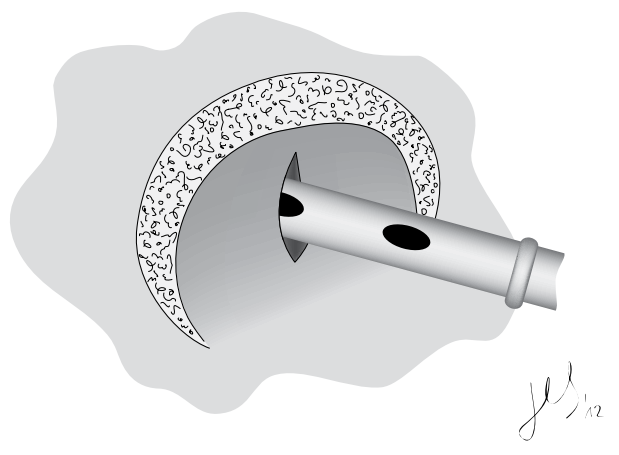

Rycina 5. Czwarty krok procedury - insercja elektrody do schodów bębenka

Figure 5. Fourth step of the procedure - insertion of the electrode to the scala tympani

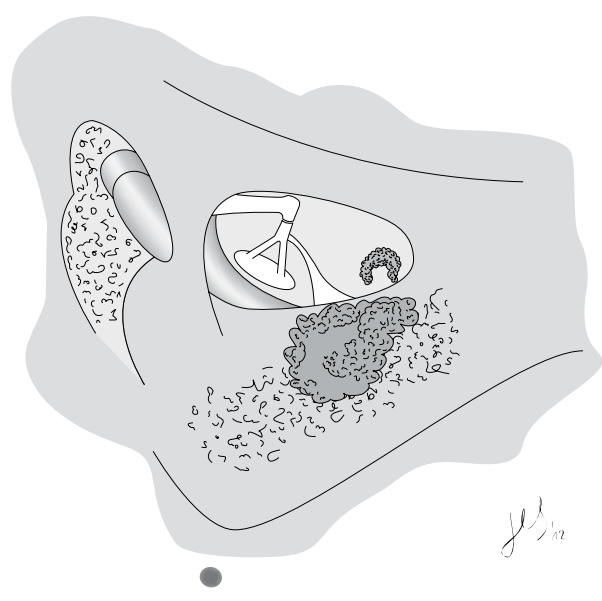

Rycina 6. Piąty krok procedury chirurgicznej - uszczelnianie i umocowanie elektrody

Figure 6. Fifth step of the procedure - electrode fixation and sealing

pacjentów dorosłych i większości dzieci drenażu ssącego i zeszyciu rany pooperacyjnej za uchem.

Do leczenia operacyjnego wykorzystano dwa systemy implantów. System Med-El z elektrodami standardowymi, których tylko część umieszczano w schodach bębenka - od 18 do $28 \mathrm{~mm}$, z elektrodami krótszymi typu Medium i Flex EAS (Flex24) o długości 20 mm, z elektrodami SoftFlex, które umieszczano od 22 do $28 \mathrm{~mm}$ w schodach bębenka (głębokie wszczepienie elektrody ma miejsce w przypadku wprowadzenia elektrody na więcej niż $25 \mathrm{~mm}$ ) [16]. Drugim systemem były elektrody firmy Cochlear typu CI422/SRA opracowane przez Skarżyńskiego, o długości $20 \mathrm{~mm}, \mathrm{z}$ możliwością głębszego wszczepienia do $25 \mathrm{~mm}$ $[12,13]$. W przypadku elektrycznego dopełnienia PDT-EC stosowano tylko stymulację elektryczną z użyciem wyłącznie procesora mowy. W przypadkach stymulacji łączonej elektryczno-akustycznej stosowano początkowo, niezależnie od systemu implantu, konwencjonalne aparaty słuchowe w tym samym uchu, a następnie system połączony Duet lub Hybryd (w jednym urządzeniu procesor mowy i aparat słuchowy). Cały proces pooperacyjnego 
[dB HL]

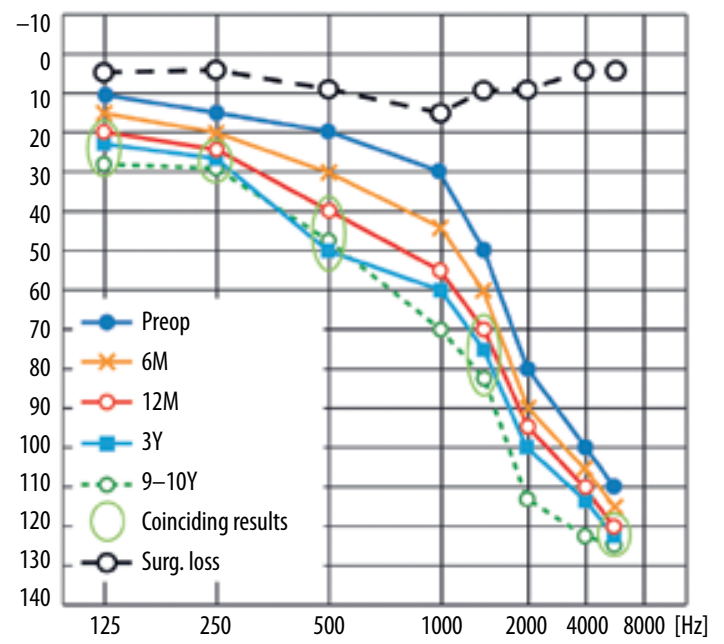

Rycina 7. Zachowanie słuchu przed operacją i po operacji w grupie PDT-EC po 9-10 latach $(n=31)$

Figure 7. Preservation of hearing before and after surgery in the PDT-EC group after $9-10$ years $(n=31)$

dopasowania systemu oraz dalszej rehabilitacji jest tematem innych opracowań [17-20].

\section{Wyniki}

Wprowadzenie nowej metody kompleksowo wykorzystującej możliwości akustycznej i elektrycznej stymulacji ucha wewnętrznego zdecydowanie rozszerzyło wcześniejsze wskazania do leczenia operacyjnego różnych wad słuchu za pomocą implantów ślimakowych z elektrodami różnej długości. Najważniejszym i najtrudniejszym zadaniem było wdrożenie w 2002 r. programu elektrycznego dopełnienia naturalnego dobrego słuchu na niskich częstotliwościach (PDT-EC) [7]. Na rycinie 7 przedstawiono przedoperacyjny słuch oraz jego zachowanie $\mathrm{w}$ grupie pierwszych 31 osób przez 9 do prawie 10 lat po operacji.

Na uwage zasługuje bardzo dobre odległe zachowanie przedoperacyjnego słuchu zarówno na bardzo istotnych niskich częstotliwościach, jak i resztkowego na wysokich. Podwyższenie progów słyszenia zanotowano dla częstotliwości $1000 \mathrm{~Hz}$ w pierwszych 6 miesiącach obserwacji. Przejściowo - do ok. 2 miesięcy - progi słyszenia były podwyższone średnio o około 10-15 dB na wszystkich częstotliwościach. Zmiany od 3 do 6 miesiąca nie były istotne statystycznie i okres 6 miesięcy w ocenie odległej wzięto jako stan wyjściowy do oceny progów słyszenia po przeprowadzonym zabiegu wszczepienia implantu w stosunku do progów słyszenia przed operacją. W okresie od 12 miesięcy do 9-10 lat po operacji nie zaobserwowano istotnego statystycznie pogarszania się słuchu na istotnych niskich częstotliwościach w pierwszej grupie operowanych 31 osób, u których zastosowano elektryczne dopełnienie. Należy tu podkreślić, że przez pierwsze dwa lata do leczenia operacyjnego w grupie PDT-EC kwalifikowano osoby dorosłe, u których w ciągu około 10 lat obserwacji przedoperacyjnej słuch był stabilny. Na rycinie 8 przedstawiono analogicznie wyniki pierwszej grupy 43 pacjentów
$[\mathrm{dB} \mathrm{HL}]$

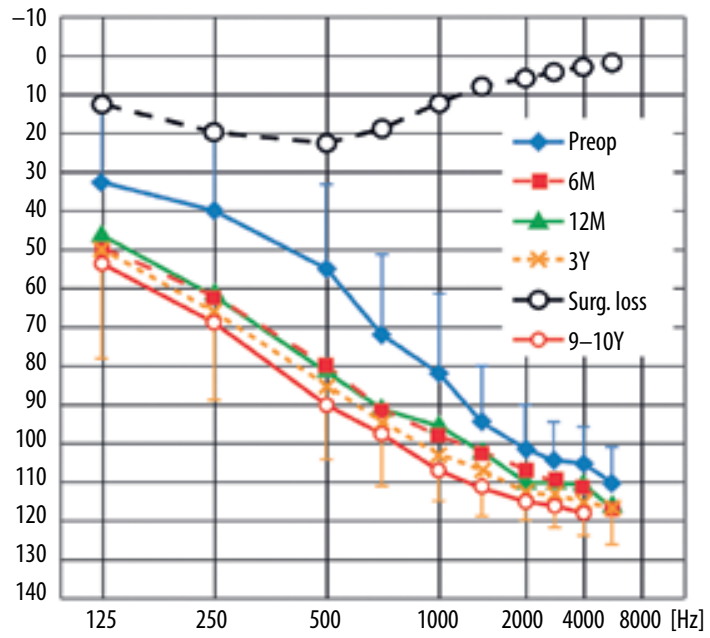

Rycina 8. Zachowanie słuchu przed- i pooperacyjne w grupie PDT-EAS po 9-10 latach $(n=43)$

Figure 8. Preservation of hearing before and after surgery in the PDT-EAS group after $9-10$ years $(n=43)$

z łączoną stymulacją akustyczną i elektryczną (PDT-EAS) przez 9 do 10 lat po operacji.

Na uwagę zasługuje podwyższenie progów słyszenia w ciągu pierwszych 6 miesięcy od 10 do $25 \mathrm{~dB}$ na niskich, najistotniejszych częstotliwościach, przy stabilnym słuchu na wysokich częstotliwościach. W dalszym okresie obserwacji przez kolejne 9 lat, słuch nie ulegał pogorszeniu. Istotne różnice $\mathrm{w}$ trwałym przesunięciu progów słyszenia w ciągu pierwszych miesięcy i ich praktycznie sporadycznym występowaniu w ciągu dalszych lat nie są łatwe do wytłumaczenia. Pewne światło rzuca na to zjawisko fakt, że w drugim, nieoperowanym uchu u około $32,5 \%$ obserwowano $\mathrm{w}$ różnym stopniu pogarszanie się słuchu. Jednocześnie analiza przedoperacyjnych wyników pacjentów pokazuje, że u 53,4\% słuch pogarszał się w niewielkim stopniu w obojgu uszach w ciągu ostatnich około 10 lat przed wykonaniem zabiegu operacyjnego. Może to oznaczać, że u tych pacjentów zarówno przed operacją, jak i po zabiegu dochodziło do niewielkiego, stopniowego pogarszania się słuchu.

Istotnym aspektem oceny wyników operowanych pacjentów jest poziom dyskryminacji mowy. Na rycinach 9 i 10 zostały zaprezentowane wyniki dyskryminacji mowy. W długim okresie - przy regularnej rehabilitacji - wyniki charakteryzują się dużą stabilnością. Stopień dyskryminacji mowy, badany za pomocą testów słów jednosylabowych, zarówno w hałasie jak i w ciszy, jest wyższy w grupie pacjentów z elektrycznym dopełnieniem słuchu (PDT-EC) $\mathrm{w}$ porównaniu z grupą PDT-EAS.

Podsumowując, należy podkreślić, że przedstawiając kompleksową koncepcję leczenia częściowej głuchoty u pacjentów z różnym przedoperacyjnym słuchem, udało się pokazać w kolejnych doniesieniach rozwój tej metody [19,21-23], a w niniejszym doniesieniu udokumentować zachowanie słuchu w czasie pomiędzy 1997 a 2014 rokiem 


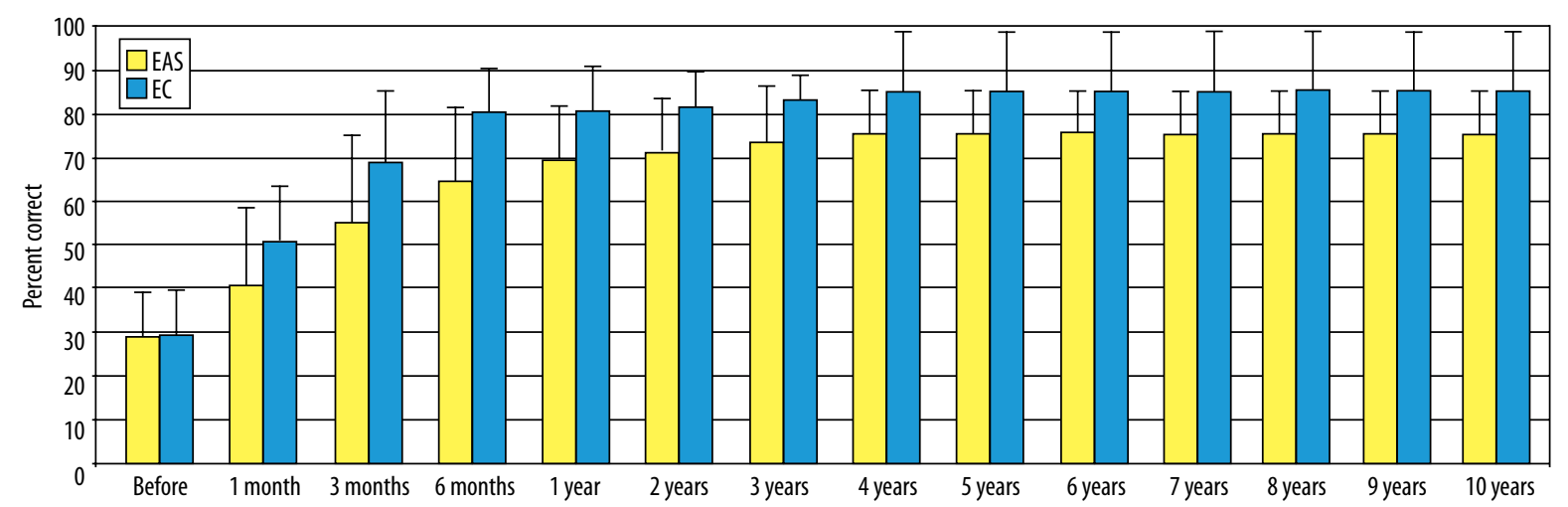

Rycina 9. Stopień dyskryminacji mowy w warunkach ciszy - monosylabowy test słowny, wyniki grup PDT-EC (niebieski) i PDT-EAS (żółty)

Figure 9. Level of speech discrimination in silence - monosyllabic word test, results of PDT-EC group (blue) and PDT-EAS group (yellow)

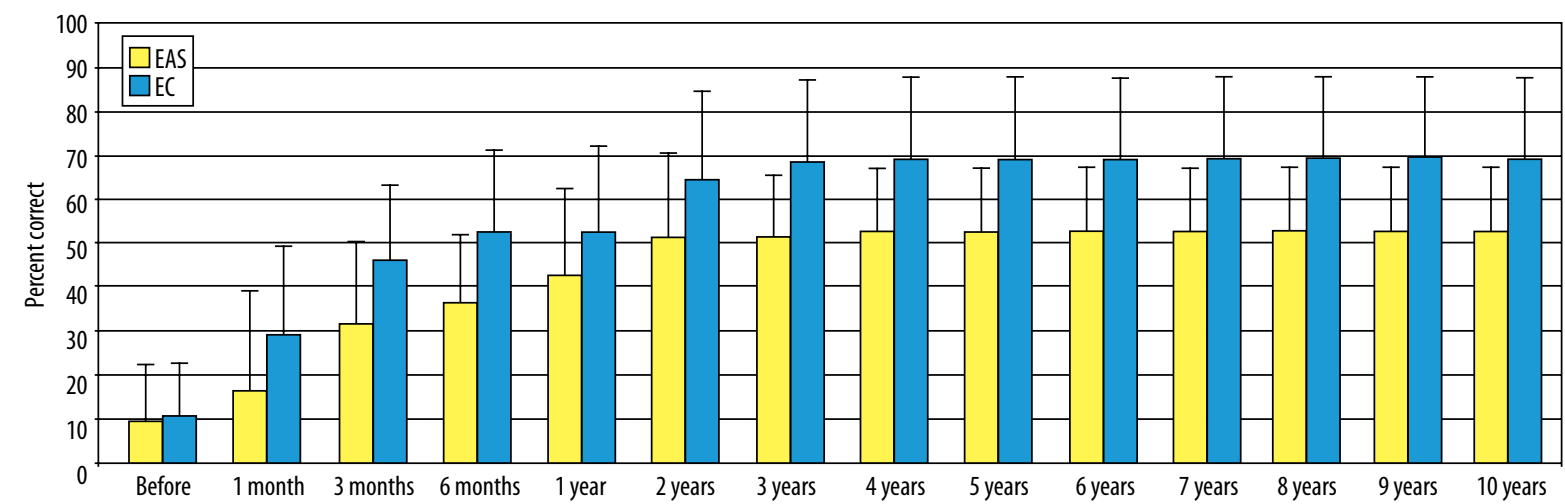

Rycina 10. Stopień dyskryminacji mowy w szumie (S/N $10 \mathrm{~dB}$ ) - monosylabowy test słowny, wyniki grup PDT-EC (niebieski) i PDTEAS (żółty)

Figure 10. Level of speech discrimination in noise (S/N $10 \mathrm{~dB}$ ) - monosyllabic word test, results PDT-EC (blue) and PDT-EAS (yellow)

u pierwszej grupy 74 osób z PDT. Uzyskane wyniki leczenia potwierdzają zdaniem autorów słuszność zarówno przyjętej klasyfikacji, jak i strategii chirurgicznej. W literaturze istnieją ponadto doniesienia na temat przeprowadzenia w różnych ośrodkach operacji analogiczną techniką chirurgiczną jak PDT oraz zastosowania analogicznych kryteriów doboru pacjentów [19,20,22,23].

\section{Wnioski}

1. Bardzo długi okres obserwacji coraz większej grupy pacjentów w różnym wieku wykazał potrzebę stałego rozszerzania wskazań do stosowania implantów ślimakowych u osób z częściową głuchotą, u których niedosłuch charakteryzuje się prawidłową czułością dla niskich częstotliwości oraz brakiem czułości dla wysokich częstotliwości.

\section{Piśmiennictwo:}

1. von Ilberg C, Kiefer J, Tillein J, Pfenningdorff T, Hartmann R, Stuerzebecher E i wsp. Electric-acoustic stimulation of the auditory system. New technology for severe hearing loss. ORL J Otorhinolaryngol Relat Spec, 1999; 61: 334-40.
2. Obserwowana przez wiele lat stabilne możliwości dyskryminacji mowy oraz bardzo dobre efekty w zachowaniu słuchu potwierdziły optymalny wybór strategii chirurgicznej z wykorzystaniem dojścia do ucha wewnętrznego przez okienko okrągłe.

3. Wyniki obserwacji klinicznych dotyczących stosowanych systemów przyspieszyły rozwój nowych technologii elektrod implantów ślimakowych wykorzystywanych w różnych systemach, co ma niezwykle ważne znaczenie nie tylko w zachowaniu przedoperacyjnego słuchu, lecz także w zachowaniu przedoperacyjnej struktury ucha wewnętrznego.

4. Wykazana niezwykle wysoka skuteczność zachowania przedoperacyjnego słuchu miała znaczący wpływ na: a) opracowanie nowych strategii wczesnego wykrywania różnych częściowych uszkodzeń słuchu na podstawie badań przesiewowych; b) nowych kierunków rozwoju zaplecza i wykorzystania technologii teleinformatycznych eZdrowia. 
3. Briggs RJ, Tykocinski M, Stidham K, Roberson JB. Cochleostomy site: implications for electrode placement and hearing preservation. Acta Otolaryngol, 2005; 125(8): 870-6.

4. Skarżyński H, Lorens A, Piotrowska A. Residual acoustic hearing in the ear before and after cochlear implantation. Presentation at the $5^{\text {th }}$ ESPCI in Antwerp, 2000.

5. Lorens A, Geremek A, Walkowiak A, Skarżyński H. Residual acoustic hearing before and after cochlear implantation. $4^{\text {th }}$ European Congress of Oto-Rhino-Laryngology Head and Neck Surgery „Past - Present - Future”. Abstract book, 13-18 V 2000, Berlin, Germany.

6. Skarżyński H, Lorens A, Piotrowska A, Skarżyński PH. Hearing preservation in partial deafness treatment. Med Sci Monit, 2010; 16(11): 555-62.

7. Skarżyński H, Lorens A, Piotrowska A. A new method of partial deafness treatment. Med Sci Monit, 2003; 9(4): 20-4.

8. Skarżyński H, Lorens A, Piotrowska A, Anderson I. Partial deafness cochlear implantation in children. Int J Pediatr Otorhinolaryngol, 2007; 71: 1407-13.

9. Skarżyński H, Lorens A. Partial deafness treatment. Cochlear Implant Int, 2010; 11 (Suppl 1): 29-41.

10. Skarżyński H, Piotrowska A, Lorens A, Szuchnik J, Walkowiak A, Śliwa L i wsp. Application of electric-acoustic stimulation in patients with profound hearing loss - case study. International Congress Series, 2003; 1240: 291-5.

11. Skarżyński H, Podskarbi-Fayette R. A new cochlear implant electrode design for preservation of residual hearing: a temporal bone study. Acta Otolaryngol, 2010; 130: 435-42.

12. Skarżyński H, Lorens A, Matusiak M, Porowski M, Skarżyński PH, James CJ. Partial deafness treatment with the Nucleus Straight Research Array Cochlear Implant. Audiol Neurootol, 2012; 17(2): 82-91.

13. Skarżyński H, Lorens A, Matusiak M, Porowski M, Skarżyński $\mathrm{PH}$, James CJ. Cochlear implantation with the Nucleus Slim Straight Electrode in subjects with residual low-frequency hearing. Ear Hear, 2014; 35(2): 33-43.
14. Skarżyński H, Matusiak M, Piotrowska A, Skarżyński PH. Surgical techniques in Partial Deafness Treatment. Journal of Hearing Science, 2012; 2(3): 9-13.

15. Skarżyński H. Ten years' experience with a new strategy of Partial Deafness Treatment. Journal of Hearing Science, 2012; 2(2): 11-8.

16. Skarżyński H, Lorens A, Zgoda M, Piotrowska A, Skarżyński $\mathrm{PH}$, Szkiełkowska A. Atraumatic round window deep insertion of cochlear electrodes. Acta Oto-Laryngologica, 2011; 131(7): 740-9.

17. Lorens A, Skarżyński H. Technologia implantów ślimakowych. Nowa Audiofonologia, 2012; 1(3): 18-23.

18. Lorens A, Zgoda M, Skarżyński H. A new audio processor for combined electric and acoustic stimulation for the treatment of partial deafness. Acta Otolaryngol, 2012; 132(7): 739-50.

19. Dorman MF, Gifford RH. Combining acoustic and electric stimulation in the service of speech recognition. Int J Audiol., 2010; 49(12): 912-9.

20. Gifford RH, Dorman MF, Skarżyński H, Lorens A, Polak M, Driscoll CL i wsp. Cochlear implantation with hearing preservation yields significant benefit for speech recognition in complex listening environments. Ear Hear, 2013; 34(4): 413-25.

21. Skarżyński H, Lorens A, D’Haese P, Walkowiak A, Piotrowska A, Śliwa L i wsp. Preservation of residual hearing in children and post-lingually deafened adults after cochlear implantation: an initial study. ORL J Otorhinolaryngol Relat Spec, 2002; 64(4): 247-53.

22. Prentiss S, Sykes K, Staecker H. Partial deafness cochlear implantation at the University of Kansas: techniques and outcomes. J Am Acad Audiol, 2010; 21(3): 197-203.

23. Helbig S, Baumann U, Hey C, Helbig M. Hearing preservation after complete cochlear coverage in cochlear implantation with the free-fitting FLEXSOFT electrode carrier. Otol Neurotol, 2011;32(6): 973-9. 